in schools, particularly in West Africa. Of the 8,315 overseas visitors in Britain in 1962-63 assisted by the Council, 1,971 were in science and technology, 1,260 in medicine, 1,399 in social science and 2,404 in education. Under the Commonwealth Scheme for university interchange, 73 awards were made to meet the cost of travel during 1962-63-41 being to university teachers on study leave, 11 to distinguished scholars invited by universities for short visits, and 21 to postgraduate university research workers holding research grants. Under the Foreign Scheme, 117 short visits by senior members of university staff were arranged, 2 longer visits by guest professors and lecturers from Britain to Germany and 79 visits for younger research workers.

\title{
THE COMMONWEALTH SCHOLARSHIP AND FELLOWSHIP PLAN
}

$\mathrm{T}$ HE third annual report of the Commonwealth Scholarship and Fellowship Plan* includes for the first time in the appendixes a special section of Commonwealth visiting fellowships and other senior awards under the Plan. Five visiting fellowships, two in Britain, two in Canada and one in India, were taken up during the year, and two Prestige fellowships, one in India and one in Australia. It is now expected that the total of 1,000 awards at any one time anticipated at the Commonwealth Education Conference at Oxford in July 1959 will be reached about the time the third Commonwealth Education Conference meets at Ottawa in August 1964, although more than 1,000 awards were made within a few months of the Oxford Conference.

During the year, including the seven fellowship awards already noted, 820 Commonwealth scholars held awards, as counted in the first terms of the awarding countries' academic year, compared with 729 in the previous year, when the total was compiled on a different basis. A significantly smaller proportion of awards was held at the undergraduate-level and there was a considerable proportionate increase in awards for higher degrees. In Britain, 467 Commonwealth scholars held awards at universities and colleges in the first term of the academic year 1962-63, and of these, 183 took up their awards in October. Extensions of tenure of scholarships were granted to 165 scholars, including 138 for studies extending into a third year, and the Commonwealth Scholarships (Amendment) Act which became law on February 28, 1963 , by removing the rigid limit of 500 awards at any

* Third Annual Report of the Commonwealth Scholarship and Fellowship Plan for the period ending 31 March, 1963. Prepared by the Association of Commonwealth Universities for the Commonwealth Education Jiaison Committee. Pp. 70. (London: H.M.S. O., 1963.) 5s. one time, enables the Commission to make fuller use of the funds at its disposal. Of the 142 scholars whose awards have come to an end since the beginning of the scheme, 41 have qualified for doctorates, 32 for master's degrees, 25 for postgraduate diplomas, 15 for first degrees and 11 for higher medical qualifications. About half these scholars have taken up academic posts on return to their own countries, and about 51 of the others have been granted permission to defer return home for a named period, with the approval of the nominating ageney.

The report expresses warm appreciation of the work of the Working Party set up by the Committee to consider the day-to-day operation of the Plan, but the report does not consider justified the criticisms levelled at the Plan by many of the developing countries at the second Commonwealth Education Conference at New Delhi on the grounds that awards for undergraduates are not available. Few nominations have, in fact, been received in Britain from overseas countries for such awards, but more such nominations are expected in 1964 in view of awards for technical education being made by Pakistan and Ceylon. Some countries expressed concern at New Delhi and in the last annual report lest extension of tenure of beyond two years to enable scholars to complete research for a doctorate should decrease the number of new awards available each year. In Britain the amended Act meets this situation, and other countries which have not yet reached their target number of awards may balance extensions against awards given for only one year. However, no clear solution is seen in the report to the recurring problem of ensuring that scholars fulfil their undertaking to return to their own country on completing the tenure of their scholarships. Any enforcement can only rest with the nominating country.

\section{ELECTROPHORESIS}

\begin{abstract}
A SYMPOSIUM on "Electrophoresis" was held in the Bacteriology Department, Anderson College, University of Glasgow, on December 12, 1963. This was the third meeting in a series of informal symposia organized. by the Department of Scientific and Industrial Research as part of their Scottish Research Laboratories Mutual Assistance Scheme. The meeting was attended by some 120 delegates from all parts of Scotland.

The chairman, Prof. R. G. White (Bacteriology Department, University of Glasgow), opened the proceedings and gave a short talk on "Immunoelectrophoresis", using recent work to illustrate the differences in antisera produced by the injection of different types of preparations of similar antigens. Prof. White emphasized the importance of recognizing these differences when antisera were being used as analytical reagents.

Dr. J. R. Norris (Bacteriology Department, University of Glasgow) described work in progress on the antigenic and enzymatic composition of Bacillus cereus cells and the changes which occur at sporulation in this bacterium. Particular attention was directed to the use of polyacryl-
\end{abstract}

amide gel electrophoresis, and Dr. Norris discussed some of the characteristics of this medium when used for sheetgel electrophoresis. A method had been developed for combining polyacrylamide electrophoresis with antigenantibody diffusion analysis in agar. The resulting discussion ranged over various aspects of the handling of the gel and the comparison of agar, starch and polyacrylamide as bases for electrophoresis.

High-voltage electrophoresis was discussed by Dr. G. Leaf (Biochemistry Department, University of Glasgow), who related a theoretical treatment to the characteristics of the technique encountered in practice. Discussion centred on the advantages of high-voltage electrophoresis over other tochniques, such as thin-layer chromatography, on voltage-levels suitable for use in various media and gels and on factors influencing diffusion of components during separation.

Dr. W. Manson (Hannah Dairy Research Institute) described the elegant system which he operated for density gradient electrophoresis using separation in a sucrose gradient to fractionate casein preparations. Dr. Manson 